\title{
SOME EFFECTS OF EMPHATIC PARTICLES ON AKAN EVIDENTIALS
}

\author{
Joana Portia Sakyi \\ University of Antwerp, Belgium
}

Summary:

The paper discusses evidentiality in Akan and demonstrates how some lexical verbs, viz, ká/sé 'to say/to allege' hú 'to see' té 'to hear' and nìm 'to know' are used to mark evidence in the language. We note in the study that these verbs possess literal as well as evidential properties which manifest at different levels of expression. Aside these lexical verbal forms, there are two verbal constructions, viz, mèhwé á 'apparently' and bìribiárá kyèré sé 'it is obvious/apparent' which are used only evidentially. Further, the paper discusses focus constructions as extensions to the basic SVO clause structure in the language. We have discussed the formation of Emphatic particles and demonstrated how they are used to consolidate the focused constituents and the asserted propositions. Generally, evidential constructions attenuate by minimizing the impact of unpleasant reactions on speakers. To find out whether the concept of attenuation occurs in all evidential contexts or not we took an experiment to come out with some findings. We found in the study, among other things, that when the source of information is focused, emphatic particles used may demonstrate certain pragmatic nuances other than emphasizing the focused constituents. In most cases, certain types of emphatic particles threaten the interlocutor's face and serves as impoliteness mechanisms. Other particles distance the speaker even further away from taking responsibility.

Key words: evidentiality in Akan, attenuation in Akan, focus constructions and emphatic particles in Akan.
Abstract:

Akan is one of the many languages which uses lexical verbs and verbal constructions to express evidentiality. In this paper, we discuss four verbs which are used as both evidential and non-evidential forms. Further, we discuss focusing strategies and the use of emphatic particles (EMPH) to support focused constituents. Our aim is to determine whether emphatic particles have any influence on evidential constructions containing them. We observed that when the source of information - the entity from whom knowledge is emanating - is focused, different degrees of attenuation/accentuation pattern is demonstrated depending on the pragmatically derived information associated with the EMPH. Normally, these particles add emphasis to focused constituents they are associated with. However, we note in this study that when certain emphatic particles are used in constructions containing evidential verbs, they not only give emphasis but also, they become pointers of face threatening mechanisms - (im)politeness depending on the interpersonal relationship existing between the interlocutors. The analysis in this study forms part of a bigger study on modality and evidentiality in Akan, based on self-created corpus from Akan literature, radio discussions, observation and constructed examples from researcher's native competence.

Key words: Akan Evidentiality, Akan Emphatic Particles and Attenuation. 


\section{INTRODUCTION}

This study examines the effects of emphatic particles on evidential constructions in Akan, a Niger-Congo Kwa language spoken in Ghana. Data for the study was collected from Akuapem Twi, Asante Twi and Fante - three of the Akan dialects which have received written status and are being studied in schools. Various aspects of the language have been studied but evidentiality has not received any attention except one on 'the expression of modality and evidentiality in Akan' by Sakyi, J. P. (forthcoming). That study presents detailed analysis of forms Akans use to express modality and evidentiality. This study is therefore geared towards the discussion of evidentiality as an attenuation strategy. It further demonstrates how the use of certain emphatic particles can mitigate the listener's face and how others reinforce a speaker's efforts to distance himself from taking responsibility.

The concept of evidentiality in the study is grounded on the premise that every authentic assertion is based on a kind of evidence, knowledge, experience, deductions or hearsay without which no constructive claims can be made (fc. Nuyts 2001/1993).

The breakdown of the remaining sections are as follows: In $\S 2$, we present an overview of our methodology showing the procedure for data collection and glossing of examples. §3 reviews literature and attempts to define some of the terms in this study. $\$ 4$ which is the focus of the paper deals with analysis of data in which evidential verbs and emphatic particles produce the impolite effect. $\S 5$ is the conclusion of the paper.

\section{METHODOLOGY}

The current study is based on a self-created corpus data complemented with constructed examples reflecting native speaker's judgments of what is syntactically, semantically or even pragmatically plausible in a particular context. The author is a native speaker of Akan who is fluent and literate in the three dialects used in the study, viz: Akuapem Twi, Asante Twi and Fante. This was crucial because as it was pointed out in Nuyts (2001a:47), native or near-native intuitions are indispensable in order to make valid fine-grinned semantic analyses in such a study.

\subsection{Data Collection Methods and Description of the Corpora}

The use of corpus data is essential for such analysis. However, like most African languages, there is currently no ready-made digital corpus for Akan. We, therefore, compiled our own corpus based on the standardized and Bureau of Ghana Languages approved writing system of the language. We were heavily restricted in the possibilities for doing so, however. Ideally, a corpus for a language is representative: it should cover a wide range of different text genres (spoken and written). In Akan culture (like in all other Ghanaian linguistic communities), however, the bulk of published texts are written in English. Publications in Akan are mainly limited to local language textbooks, literature and religious materials. We, therefore, compiled a representative 
corpus of written Akan from these books. Since these published materials are not available in electronically, we had to work in part with the printed hard copies. In all, we used about 65 printed Akan books, including the Bible, literary prose, poetry, drama, pedagogical materials and a few published and unpublished journal articles. We read through these books to extract evidential forms manually - including sufficient amount of context to support the analysis.

In addition, we managed to get access to fifteen electronic texts including Creative Writing long essays by Akan Students of University of Education - Winneba, Fante books awaiting publication, texts from a few online sources, the UN Human Rights charter and parts of the Bible. We used WordSmith software to search these softcopies for relevant forms.

The printed and electronic texts together consist of approximately 1,700,000 words. The word count for the electronic texts is very precise, of course. But the counts for the hard copies are an approximation. Next to the written data, we also compiled an inevitably limited spoken data to support the printed texts. On the $12^{\text {th }}$ and $13^{\text {th }}$ December 2013, we taped about 12:42 hours of a radio broadcast from Peace FM - Accra. This radio station mainly uses Akan in its broadcasts. The broadcast included radio news, advertisement, motivational messages and discussions, among others. Although we were not able to transcribe all these data, we listened to them several times and wrote down the interesting sentences for analysis. In order to estimate the number of words in the broadcasts, we transcribed small portions of different parts suggesting an average of 160 words per minute. Hence, we had a total of about 122,000 words of spoken data.

Overall, we identified 4 lexical verbs and 2 verbal constructions which express evidentiality. There were only 4 instances of emphatic particles occurring in evidential constructions.

It is best to combine corpus data with intuitively constructed examples to be able to account for constructions which may not appear in corpus. Leech (1991:74) argues that the use of a corpus is a question of corpus plus intuition, rather than of corpus or intuition (see Byloo 2009:14, who also supports the use of both corpus and intuition). For this reason, we have constructed examples from intuition and constructed a few based on the data available to enhance our discussion of such constructions. We also used Akan speakers in Ghana and Antwerp as informants, noted their utterances containing interesting forms on daily basis and tagged them as observed (OBS) in the examples.

Table 1.1 gives an overview of our corpus indicating the estimated number of words in the different corpus categories.

\begin{tabular}{|l|l|c|}
\hline Type of Books & Number of Books & Est. Number of Words \\
\hline Published Books & 65 & $1,604,834$ \\
\hline Unpublished Books & 15 & 109,915 \\
\hline Web Sources & 3 & 9,272 \\
\hline Radio Broadcast & 12 hrs. 42mins. & 122,000 \\
\hline Total & & $1,846,021$ \\
\hline
\end{tabular}

Table 1.1 Type of Books with Estimated Number of Words

Normas (ISSN: 2174-7245)| 


\subsection{Glossing}

Glossing in the study is based on the Leipzig glossing rules. For each example presented, the first line is the data-line; i.e. the way it appeared in the corpus. Tone does not feature in Akan orthography so this first line is left untoned. The second line which gives the morphological analysis is presented with tones. The third line is reserved for glosses of the morphological analysis, while the fourth line gives the free translation. We try as much as possible in our translation to be faithful to the original utterance. Nevertheless, readers should be careful when using the English translations in the interpretation of examples since certain constructions cannot be rendered in English. Where necessary, we have added the 'literal translation' in brackets for better understanding.

All examples we quoted from published and unpublished books in the corpus are presented as they appear. Examples quoted from scientific literature are also left in the way they appear in the original text, but since various writers use different glossing styles, glosses have been adapted to our present style.

Since data covers the three dialects of Akan, we indicate the source with an abbreviation of the book title followed by an abbreviation of the dialect. A Fante example from the book 'Abotar', for instance, is tagged as (ABO FA).

\section{DEFINITIONS}

\subsection{Evidentiality}

There are varied ways of expressing the notion of evidentiality in different languages. Aikhenvald (2004:1) indicates that in about a quarter of the world's languages (she studied), every statement must specify the type of source on which it is based - for example, whether the speaker saw it, or heard it, or inferred it from indirect evidence, or learnt it from someone else. Boas (1938:133) had earlier on identified these languages as languages in which indicating the source of information is obligatory. One must indicate whether the state of affairs given was seen, heard or inferred from available evidence. These languages have dedicated affixes which indicate their source of information.

Aikhenvald (2004:10) mentions that "Every language has some way of referring to the source of information, but not every language has grammatical evidentiality." Of course, the way languages express various categories may differ, but it is the existence of the said category in a language which is important. Chafe (1986:261) noted concerning languages which exhibit evidentiality grammatically as opposed to English which uses lexical forms that "the difference between these Indian languages and English, is not a matter of evidentials vs. no evidentials. It is partly a question of how evidentiality is grammatically expressed: is it by suffixes, auxiliaries, adverbs or what?" Studies have revealed languages in which evidentiality may be expressed, among other things, by modal auxiliaries. These forms may express both evidentiality and epistemic modality (see Coates 1983; Palmer 2001; van der Auwera and Plungian 1998; Bybee et al 1994, among others). And yet in other languages, evidential forms are completely different 
from modality markers. Akan may be classified as one of such languages in the sense that in all instances, the identified forms indicate only evidence for modalized or non-modalized assertions.

Considering how Akans code evidentiality in clauses, it is wise to adopt a working definition of the concept to delimit our scope. We will, therefore, follow Aikhenvald's (2004:3) concept which says that "evidentiality is the linguistic category whose primary meaning is source of information". Aside the grammatical realization of evidentiality she discussed, Aikhenvald (2004\&2007) noted that lexically, evidentiality may be expressed by perceptual verbs, particles, parentheticals, adverbs, etc. The question now is how Akans express evidentiality. Akans use verbs and verbal constructions to express evidentiality. Some of the forms we consider in this paper are the lexical verbs ká/sé 'to say', té 'to hear', hú 'to see' and nim' 'to know'. These verbs have both literal and evidential properties they demonstrate contextually in utterances. The verbal constructions biribiárá kyèré ś 'it is evident/evidently' or 'it is apparent/apparently' and (wó) hwé á 'obviously/it is obvious' or 'it seems' have only evidential properties. Note that the semantics components of these verbal constructions correspond to English adverbial and adjectival forms. This is to be expected because it has been pointed out in Sakyi (2013) that Akan does not have evidential adverbs and adjectives; and that, most of the evidential adverbs and adjectives in English and in some of the European languages are expressed with verbal constructions.

\subsection{Attenuation}

The process of mitigating or lessening effects of otherwise harsh and unpleasant propositional content is achieved through attenuation devices. There aren't specific lexical items which are solely dedicated to attenuation, though. Thus, Estellés and Albelda (2014:37) argue that attenuation is a pragmatic category that can apply to virtually any level of language to produce specific pragmatic effects. Since it is its objective to mitigate potential damage towards the interlocutors' face, attenuation often results in politeness, although that is not the only function played by attenuation. In this paper, we recognize how evidentiality as a super-category in linguistics is used as an 'attenuation frame'. Using evidentiality to support assertions which may not be pleasant to listeners is one way of attenuating in the sense that the speaker attributes all the damaging effects associated with the utterance to a different entity. Estellés and Albelda (ibid) has it that "The underlying reason why speakers use evidentials as attenuating devices is that, through using them, speakers are no longer the source of the utterance, which is attributed to someone else." They explained further that when the speaker expresses his/her lack of responsibility towards these words, he/she can legitimately disagree with their content, thus soothing the damage caused by the message contained in the utterance, be it damage towards the addressee, or towards him/herself. This intended mitigation effect which goes a long way to sooth damages caused to interlocutors' face is what Coates (1987:122) also observes that "...it is important for speakers to avoid making outright assertions: each speaker must allow room for further discussion and for the modification of points of view". We must, however, already point out that, although the entire notion of evidentiality is considered here as attenuating potential damaging utterances, it is not in all contexts of evidentiality which present

Normas (ISSN: 2174-7245) | 
attenuation. In instances where the speaker uses his own personal experience or knowledge to indicate his evidence for an assertion, such mitigating effects cannot be achieved. Moreover, in instances where a speaker is the sole experiencer of evidence, there is no need for him/her to try to attribute it to any other person or entity. We note further that, although there is attenuation in the overall use of evidentiality, there is also the issue of (im)politeness where emphatic particles occur in evidential constructions. This must be expected because when it comes to pragmatic interpretations, a variety of things come to play. Urbanová (2003) points out that Pragmatic means are context-sensitive: the same pragmatic means can be interpreted as means of attenuation in certain contexts, while in others as accentuation devices.

Considering the function of emphatic particles in utterances, for example, they should be adding emphasis to the focused constituents they are attached to. In addition to that, however, we can see these particles playing other pragmatic roles such as lending themselves as (im)politeness mechanism in evidential clauses containing them.

\section{3 (Im)politeness}

The processes whereby a speech partner demonstrates consideration or not to the other partner is considered (im)politeness. Expression of (im)politeness is culturally or socially bound; as such, a speaker can sometimes express politeness using boosting, intensification and other devices socially recognized and understood by the speech parties (see Estellés and Albelda 2014). In line with this observation, we note that some of the emphatic particles discussed in this paper are boosting or intensification devices which do not only function in utterances as pragmatic politeness but also impoliteness strategies in certain contexts. According to Leech (1983:139), "Politeness is manifested not only in the content of conversation, but also in the way conversation is managed and structured by its participants". A speaker may structure his conversation to positively or negatively enhance the face of the listener. According to Brown \& Levinson, (1987: 311). "Face is something that is emotionally invested, and that can be lost, maintained, or enhanced, and must be constantly attended to in interaction." Attending to face positively is always desirable, but the use of kóráá and mpó 'even' to focus source of information is a way of reducing the listener's face rather than boosting only.

\subsection{Indicating Evidentiality with Verbs}

This section presents an overview of lexical verbs ká/sé; té; hú and nimi used to indicate evidence in utterances. As lexical verbs, they are used literally to talk about entities. Evidentially, they play the role of indicating evidence for assertions and also pointing to the way information or knowledge was acquired. Ká/sé marks reportative evidentiality in which case it means 'it is said, allegedly, reportedly or according to.' Té is used when the information is hearsay, in which case the speaker merely quotes what $\mathrm{s} /$ he heard from a previous speaker. The state of affairs could also be the speaker's own evaluation if s/he acquired the information or heard about it by him/herself. Hú 'to see' is used to indicate visual evidence while nim' 'to know/be aware of' is one of the mental state verbs used as the basis for assertions. 'To know' has been one of the few forms discussed under either epistemic modality or evidentiality. Nuyts (2001:111) for

Normas (ISSN: 2174-7245) | 
example considers it as an epistemic modal form to indicate certainty. He describes it as a form which means: "I consider it (quite) certain/I am convinced that... although I have no hard proof for it and can only say so on the basis of intuition."

The form has also been described as a cognitive verb which can express common knowledge as the source of information. Storch, Anne and Jules Jacques Coly 2014: 205) describe knowledge as expressing different ideas including referring to source of information in Maaka, a language of north-eastern Nigeria. They indicate that in that language "this verb can also express common knowledge as the source of information. In rhetorical questions, it evokes implied answers about shared wisdom." They presented examples in which the speaker refers to a habit that is common knowledge and therefore true. They further noted that the form emphasizes possession and control of knowledge, exclusively shared insights and the common experience of truth. The situation in Akan is not different from what has been described here. In Akan, the form expresses evidence, possession of knowledge and indicates source of information rather than modal certainty. In the utterances that follow, what the form expresses is being aware of information or being knowledgeable about the state of affairs under consideration. As an evidential marker, it determines the grounds for asserting the state of affairs in the complement clauses.

\subsection{Focus Constructions and Emphatic Particles}

The basic clause structure of Akan is SVO with varied modifications. One of such modifications is the concept of focusing strategy. Focus is taken to be a syntactic feature assigned freely to word level categories (see Drubig 2000). Studies on focusing identify two classifications; those with prosodic prominence and those with morphosyntactic focus structures, of which Akan happens to be one of such languages. Focusing has been studied in the language by (Boadi, 1974; Ellis and Boadi, 1969; Ofori, 2011; Saah, 1988; Marfo, and Bodomo, 2005 and Schachter, 1973). It has been noted in these studies that all the major word classes - verbs, nouns, adjectives, adverbs, etc. - can be focused. Focused constituents occur at the left periphery of the actual clause, also known as presupposed component, old or shared information (See Lambrecht 1994; Ofori 2011).

Emphatic particles in Akan are a closed class of particles used to mark focused items or parts of utterances. They emphasize preceding constituents and have been referred to in the language by some writers as focus markers (see Boadi 1974; Ofori 2011). We use the term emphatic particle in this study for clarity. In describing their scopal interaction in Japanese, Ishikawa (2011) points out that emphatic particles "are concerned with connecting discourse presuppositions with the assertive content of the current utterance." This view is prevalent in the particles discussed in this study in the way they connect focused items (denotatum) to main clauses. It also supports Boadi's (1974) view quoted by Ofori (2011) concerning the particle nà (the other particles in general as well), that the focus marker is "an exclusive focus marker, an individuating deictic, (a formative) emphasis' which attaches itself to an NP to present that NP as new information, and then narrows down its (the NP's) referential range, thereby placing it in an exclusive class by itself."

Normas (ISSN: 2174-7245) | 
This definition has been challenged by (Ofori 2011) with the view that the focus marker rather helps to express a complete assertion and does not simply qualify the focused unit in the terms described above. These views as well as Ellis and Boadi's (1969:7-8) claim that the modified unit "becomes the focus of the message being transmitted" are all true to certain levels of interpretation, especially when dealing with simple sentences. In complex clauses where the speaker uses an emphatic particle to focus his/her source of information, the focused constituent not only become one of the important focal points in the message being transmitted but also a comparable entity to the listener's status. As such, when the pragmatic nuances associated with the emphatic particle is negative, the face of the listener is threatened.

In many respect, these particles are the carries of emphasis and reinforcement for their focused hosts. We consider 4 of these particles in this study, viz: ḿpó 'even' kóráá 'even' árá '(...) self' and nà 'that/who'. Aside their semantic contents, they also have pragmatic nuances which go a long way to affect all the interlocutors (speaker, listener and source of information alike) in one way or the other.

In forming a focus sentence, the full sentence to be manipulated (presupposed information) must be intact. Boadi (1974) demonstrated that since focusing is an additional information to the already existing sentence, the emphatic particle to be considered is placed at the left periphery of presupposed sentence. The sentence constituent to be focused (denotatum) is then placed at the left periphery of the emphatic particle. Taking the sentence below as an example, we show how focusing in simple sentences occur according to Boadi (ibid).

1. Kofi frę abofra no. (CONS AK)

Kòfí fré-̇̀ àbòfrá nó.

Kofi call-PAST child DET

'Kofi called the child.'

In the first step, the emphatic particle is placed on the left periphery of the sentence

2. [dé Kòfí fréc̀ àbòfrá nó]

In the second step, the constituent to be focused is also placed in front of the emphatic particle, in this case the verb.

3. Fre de Kofi frec abofra no.

Fré dé Kòfí fré-غ̀ àbòfrá nó.

calling as for Kofi call-PAST child DET

'As for calling, Kofi called the child.'

Note that when the verb of the sentence is to be focused, it is nominalized but the one in the main sentence is intact.

To focus the subject of the sentence, the same processes are followed to generate 
4. Kofi de Kofi frę abofra no.

Kòfí dé Kòfí fré-̇̀ àbòfrá nó.

Kofi EMPH Kofi call-PAST child DET

*'As for Kofi Kofi called the child.'

Boadi (ibid) notes at this level that since the focused Kofi is co-referential to Kofi in the main clause, an obligatory pronominalization rule is applied to convert the one in the main sentence into a pronoun.

5. Kofi de गfrę abofra no. (CONS AK)

Kòfi dé j̀fré-̇̀ àbòfrá nó.

Kofi EMPH 3SG-call-PAST child DET

'As for Kofi he called the child.'

The processes is applicable to complement clauses containing source of information. In this case, the whole construction is taken to be the old information.
6. Nkrıfo ka se Ama papa aba. (AGY AS)
Ǹkrjłójó ká sé Ámá pàpá á-bà.
People say COMP Ama.POSS father Perf-come
'People say/it is alleged that Ama's father has come.'

To focus the source of information, the emphatic particle and the source of information are placed on the left periphery to generate

7. Nkrofo na nkrofo ka se Ama papa aba.
Ǹkròfój́ nà ǹkrjóój ká sé Ámá
pàpá á-bà
people EMPH people say COMP Ama.POSS father PERF-come
*'People it is people who say that Ama's father has come.'

The obligatory pronominalization rule is applied to convert the second noun into a pronoun

8. Nkrofo na wıka se Ama papa aba.
Ǹkròfój́ nà wó-ká sé Ámá pàpá ábà
people EMPH 3PL-say COMP Ama father PERF-come
'It is people who say that Ama's father has come.'

\section{ANALYSIS}

Two parameters taken into consideration for the analysis here are (a) Speaker's involvement and (b) Listener's face. Speaker's involvement concerns how the speaker uses an emphatic particle to distance himself further away from responsibility. Normally, when a speaker indicates his source of information, he does not take responsibility for any damaging effect emanating from the utterance. In addition, the presence of árá or nà semantically adds emphasis and at the same time withdraws the speaker even further from claiming responsibility. For instance, 
when a speaker utters (9), he is attributing responsibility to the source of information. It therefore attenuates.

9. Jkaa se गbeba. (Boadi 2005:75, AS)

j̀-kà-à $\quad$ ś́ j̀-bé-bá.

2SG-say-PAST COMP 2SG-Fut-come

'He said that he would come.'

If someone presented the state of affairs in (9), we would expect a positive occurrence of the state of affairs due to the confidence residing in the utterance. However, since we are assessing a future occurrence, we could also expect a threat; it could as well not occur. Thus, the moment the speaker indicates his source of information as the subject's own utterance, our confidence is increased. The whole utterance could, therefore, be taken to indicate that ' $\mathrm{He}$ said he would come, so I am confident that he comes' or 'He said he would come, but he didn't, as such I am disappointed in him.'

Apart from distancing himself, the speaker is also indicating that if the state of affairs does not materialize, it is the source of information (and not the reporter) who has to be blamed or held responsible.

10. Jno na skaa se วbeba. (CONS, AS)
j̀nó nà
j-ká-á
SÉ
j-bé-bá.

3SG EMPH-that 2SG-say-PAST COMP 2SG-Fut-come

'He is the one who said that he would come.'

The second parameter has to do with whether the use of the emphatic particle threatens or support the listener's positive face. In (11), the speaker presents both the assertion and the source of information.

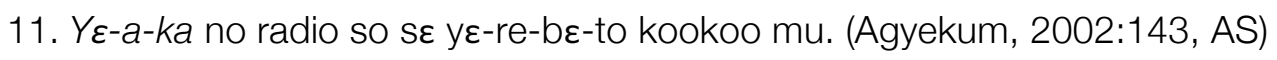

$Y \varepsilon$-à-ká nò rádió só sé

1PL-PERF-say $3 S G$ radio on COMP

yغ̇-rè-bè-tó kòòkóò mú.

1PL-PROG-come-increase cocoa in

'It has been said/reported on the radio that cocoa price would be increased.'

The proposition means my source of information for asserting an increase in cocoa prices is the radio; I did not cook the story. In (12) however, another level of interpretation is revealed.

12. Ye-a-ka no radio koraa so se ye-re-be-to kookoo mu. (Agyekum, 2002:143, AS)
$Y \dot{\varepsilon}$-à-ká
nò rádió koraa só sé

1PL-PERF-say 3SG radio even on COMP

$y \grave{\varepsilon}-r e ̀-b \dot{\varepsilon}$-tó

kòòkóò mú.

1PL-PROG-come-increase cocoa in

'Even the radio has said/reported that cocoa price would be increased.' 
The use of the emphatic particle indicates that if the radio has reported an issue, who are you (the listener) to doubt it or say something different. Pragmatically, this is a clear example of face threat or showing impoliteness to the listener.

In what follows, we present examples which correspond to the two parameters described above.

13. Mate se nea worekı no mmabaa ano bəre sen aboa swı de. (BRA, AK)

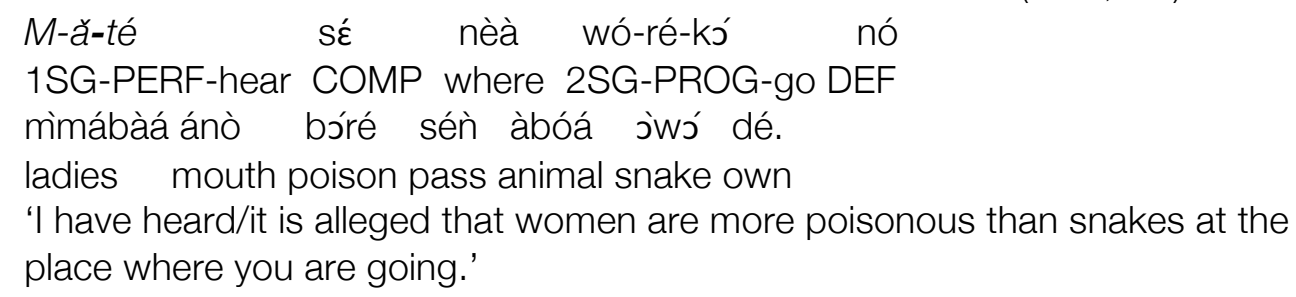

14. (Me mpo) mate $s \varepsilon$ akromfo abswia ne nnesma nyinaa. (Agyekum, 2002:131, AS)

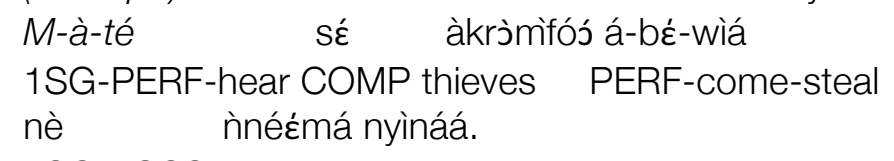

Măté in (13) and (14) contains the first-person subjects but they are not the source of information. They are both referring to allegations and so they both attenuate; but whereas (13) remains silent on the status of the listener, (14) involves the speaker comparing himself to the listener thereby implying impoliteness.

The speaker in (15) gives the source of information for asserting the proposition in the utterance and since he is the source of information (because he used his own sight to acquire the information) there is no attenuation. He is rather exerting authority and confidence on the listener.

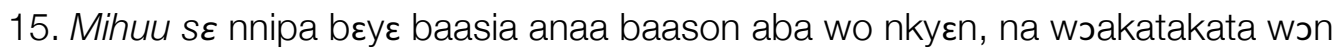
anim wo sum no mu. (JUL, AK)
Mì-hú-ú sé ǹnípá béyć bààsiá ànáá bààsóń
1SG-see-PAST COMP people about six or seven
á-bà wò ǹkyéń, nà wò-à-kátá.kàtà
PERF-come 2SG.POSS self CONJ 3PL-PERF-cover
wòn àním wò súḿ nó mù.
3PL.POSS face in dark DET in
'I saw that about six or seven people had come to you, and they had covered their faces in the darkness.' 
Examples (16 \& 17) are among the few instances where emphatic particles occurred with evidential constructions in our corpus. In both instances, the speakers are referring to themselves as sources of evidence for their claims. Aside from the fact that both constructions do not attenuate, they also provoke listeners' face threat. Pragmatically, speakers are saying they themselves have adequate knowledge about the states of affairs and as such listeners' views are not welcomed.

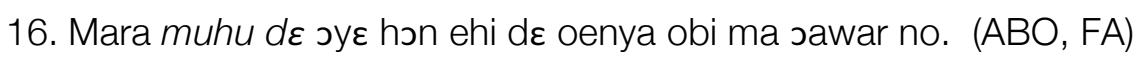
M-árá mú-hú dé j́-yé hòn èhí dé 1SG-EMP-self 1SG-see COMP 3SG-do 3PL jealous COMP ó-é-nyà òbí mà j̀-á-wáŕ nó. 3SG-PERF-get someone give 3SG-PERF-marry 3SG.

'I myself, it is apparent to me that they are jealous that she has gotten someone to marry her.'

17. Me ara mihu se ebia $\varepsilon n k a a$ me nna santen bi bio $\varepsilon$. (BRA, AK)

Me ara mi-hu se ebia $\varepsilon$-n-ka-a

1SG EMP-self 1SG-see that perhaps 3SG-Neg-remain-PERF me nna santen bi bio $\varepsilon$.

1SG.POSS days plenty some again

'It is apparent to me myself, that perhaps I am not left with many days to live.'

The use of nim in the following sentences indicates that the states of affairs are factual. Being factual states of affairs, it is assumed that the listeners are aware of them or have knowledge about them.

18. Hmm, maame enye saa O! wo ara wonim se medi no ba koro. Afei nso $\varepsilon n n \varepsilon$


AS) máàmé è-n-yć Sàá Ò! wó árá $\mathrm{Hmm}$, Hmm, maame 3SG-NEG-be DEM O! 2SG EMPH wó- $\varnothing$-nìm sé mè-dí nó bà kóró. 2SG-STAT-know COMP 1SG-eat 3SG child one. Áféí ńsó ènné sùkúú yí á á-bá yí, Also again today school DET REL PERF-come DET, wó- $\varnothing-p \dot{~}$ sé wò bá $\varnothing-k j ̀$ bí 2SG-STAT-like COMP 2SG.POSS child INF-go some ná j’-kj̀ nò yíé á, CONJ 3Sg-go 3SG good CM,

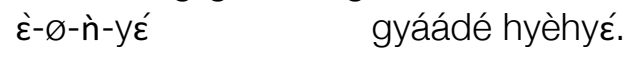
3SG-STAT-NEG-be kitchen enter.

'Hmm, mother that is not the case! You know it yourself that she is the only child I 
have. Moreover, if you want your child to excel in today's type of schools, you should not allow her to be working in the kitchen too often.'

In (18), the occurrence of the emphatic particle in the construction indicates that the listener might have said something he shouldn't have said based on the general truth in the state of affairs at hand. The whole construction, therefore, comes as a face threat resulting in impoliteness.

19. Wudi mu awerchow ne mmuada a, wo nso w'ahosden so behuan. Nanso wunim se ahosden yi ara ne nkwa; $\varepsilon s a$ a, na nkwa asa. (JKR AK)

Wú-dì mú áwèržhów nè mmùàdá á, wó nsó

2SG-eat in sad CONJ starving CM, 2SG also

W'áhòj̀dén sò bé-húán.

2SG.POSS'-strength on FUT-reduce.

Nàńsó wú-Ø-nìm sé àhòj̀dén yí árá né

But 2SG-STAT-know COMP strength DEF EMPH be

nkwá; ć-sà á, ná nkwá á-sà.

life; 3SG-finish CM, then life PERF-finish.

'When you brood and starve yourself too much (because of death), you will also become weak. But you know that strength is life, when strength is gone, life is gone.'

Another factual claim is presented in (19). The use of nim indicates that the source of information is based on general knowledge.

\section{CONCLUSIONS}

We have, thus far, looked at how evidentiality is used as an attenuating mechanism. Our results support earlier studies that evidentiality as a category is an important strategy for attenuation. The study has also proved that it is not all evidentially marked utterances which attenuate because when the evidence is speaker's own experience, there is no attenuation. Further, we have demonstrated that in the environments of evidentials, emphatic particles not only function as emphasizers but also, they pragmatically indicate (im)politeness. That is to say, evidentially attenuated utterances are rendered (im)polite in the face of emphatic particles.

\section{REFERENCES}

Aikhenvald, Alexandra (2004). Evidentiality. Oxford University Press Inc., New York, United States.

Aikhenvald, Alexandra (2007). Information source and evidentiality: what can we conclude? Italian Journal of Linguistics/Rivista di Linguistica.

Auwera, Johan van der and Vladimir A. Plungian (1998). Modality's semantic map. Linguistic Typology 2: 79-124. Boadi, Alexander L. (1974). Focus marking in Akan. Linguistics 140, 5-57.

Boas, Franz (1938). General Anthropology. D. C. Heath and Company, United States of America.

Brown, Penelope and Stephen C. Levinson. 1987. Politeness: Some universals in language usage. Cambridge: Cambridge University Press. [First published 1978 as part of Esther N. Goody (ed.): Questions and Politeness. Cambridge University Press]. 
Bybee, Joan L., Revere D. Perkins and William Pagliuca (1994). The Evolution of grammar: Tense, aspect and modality in the languages of the world. Chicago: University of Chicago Press.

Byloo, Pieter (2009). Modality and Negation. A corpus-Based Study. Doctoral Thesis. University of Antwerp.

Chafe, Wallace and Johanna Nichols (Eds) (1986d). Evidentiality: The Linguistic Coding of Epistemology (Advances in Discourse Processes (v.20). Praeger.

Coates, Jennifer (1983). The semantics of the modal auxiliaries. London: Croon Helm.

Coates, Jennifer (1987). Epistemic Modality and Spoken Discourse. In: Transactions of the Philosophical Society. Basil Blackwell, Oxford.

Drubig, H. Bernhard (2000). Towards a typology of focus and focus constructions. University of Tübingen.

Ellis, J. \& Boadi, L.A. 1969. To 'Be' in Twi. In: J.W.M. Verhaar (ed.), The Verb 'Be' and its Synonyms, Part 4, pp. 171. Dordrecht: D. Reidel.

Estellés, M and Marta Albelda Marco (2014). Evidentials, Politeness and Prosody in Spanish. Journal of Politeness Research 2014; 10(1): 29-62. Mouton Gruyter De.

Ishikawa, A. (2011) Emphatic Particles and their Scopal Interaction in Japanese.

Lambrecht, K. 1994. Information Structure and Sentence Form: Topic, focus and the mental representations of discourse referents. Cambrigde: Cambrigde University Press.

Leech, G. (1991). The state of the art in corpus linguistics. In: K. Aijmer and B. Altenberg (eds.) English corpus linguistics: Studies in honour of Jan Svartvik. London: Longman, 8-29.

Leech, G. N. (1983). Principles of pragmatics. London: Longman, pp.xiv +250

Marfo, C. and Adams Bodomo (2005). Information Structuring in Akan Question-word Fronting and Focus Constructions. Studies in African Linguistics 34(2): 179 - 208, David Odden (ed.). Ohio State University (The department of Linguistics and the Center for African Studies) - Columbus Ohio

Nuyts, J. (1993a). Epistemic modal adverbs and adjectives and the layered representation of conceptual and linguistic structure. Linguistics 31: 933-969.

Nuyts, J. (2001). Epistemic Modality, Language, and Conceptualization. John Benjamins Publishing Company. Amsterdam/Philadelphia.

Ofori, Antwi S. (2011) On the Basic Focus Marker, and the Basic Focus Sentence, in Akan (Twi) Nordic Journal of African Studies 20(3): 241-262 (2011)

Palmer, F. R. (2001). Mood and Modality. 2nd edition. Cambridge: Cambridge University Press.

Saah, Kofi K. (1988). Wh-questions in Akan. Journal of West African Languages 18, 17-28.

Sakyi, J. P. (2013). Modal Adverbs and Predicative Modal adjectives in Akan. Selected Proceedings of the 43rd Annual Conference on African Linguistics, (ed.) Olanike Ola Orie and Karen W. Sanders, 188-195. Somerville, MA, USA: Cascadilla Proceedings Project.

Sakyi, J. P. (Forthcoming). Expression of Modality and Evidentiality in Akan.

Schachter, Paul (1973). Focus and relativization. Language 49, 19-46.

Storch, Anne and Jules Jacques Coly (2014). The grammar of knowledge in Maaka. In Aikhenvald, A. and R. M. W. Dixon (eds), The Grammar of Knowledge - a Cross-Linguistic Typology. Language and Culture Research Cerntre, James Cook University. Oxford University Press, Oxford.

Urbanová, Ludmila (2003) On Expressing Meaning in English Conversation: Semantic Indeterminacy. Spisy Masarykova univerzita.

Normas (ISSN: 2174-7245)| 